\title{
Structure of the Sierra de Lujar (Alpujarride Complex, Betic Cordillera)
}

\author{
Estructura de la Sierra de Lújar (Complejo Alpujárride, Cordillera Bética)
}

\author{
Carlos Sanz de Galdeano ${ }^{1}$, Angel Carlos López Garrido ${ }^{1}$ \\ ${ }^{1}$ Instituto Andaluz de Ciencias de la Tierra (CSIC - Univ. de Granada). Facultad de Ciencias.18071. Granada, España. \\ Email: csanz@ugr.es
}

\begin{abstract}
The Sierra de Lujar constitutes one of the best examples of fold superposition of the Internal Zone of the Betic Cordillera (S Spain). In this paper, the members of its Triassic carbonate series have been used for the first time to obtain the cartography of the Sierra de Lujar, providing knowledge of the two folding systems, the older trending E-W and the younger (far better represented), NNE-SSW.

The most important fold is a large reverse syncline with a convex axis towards the SE, forming part of the $S$ and $\mathrm{E}$ edges of this sierra; contrarily, the vergence is towards the $\mathrm{N}$ in the southern sector and towards the $\mathrm{W}$ in the eastern sector. The interior of the Sierra de Lujar bears a succession of NNE-SSO anticlinal and synclinal folds, some with reverse limbs. The vergences fluctuate, even within the same fold. Folds of an E-W system crop out only in the SW sector of the Sierra de Lujar and verge to the S. The unit of the Sierra de Lujar (Lujar-Gádor unit) is overthrust by the Escalate unit (which is a duplication of the Lujar unit) and by other upper units, formed here by schists. The W edge of the Sierra de Lujar is affected by a large normal fault that sinks the Escalate unit there. The E-W folds were coetaneous with the thrusting of the units, while those in the NNE-SSW direction formed at the onset of the westward shift of the Internal Betic-Rif Zone.
\end{abstract}

Keywords: fold superposition; nappe; Alpujarride; Betics internal Zone; Spain

\section{RESUMEN}

La Sierra de Lújar constituye uno de los mejores ejemplos de superposición de pliegues de la Zona Interna Bética. Su estructura se ha determinado a partir del primer mapa en el que se han distinguido los diferentes tramos de su serie triásica carbonatada. Los pliegues NNE-SSO son los más abundantes y se superponen a otros de dirección E-O. Los bordes S y E de esta sierra corresponden en parte a un gran sinclinal invertido vergente hacia su interior y que continúa en la Sierra de La Joya pero con distinta vergencia. En el interior de la sierra hay numerosos anticlinales y sinclinales de dirección NNE-SSO, algunos de flancos invertidos cuyas vergencias varían incluso en un mismo pliegue. La unidad de Lujar es cabalgada por la de Escalate (una duplicación de la de Lujar) y por otras superiores. El borde occidental de la Sierra de Lujar está afectado por una falla normal que hunde la unidad de Escalate. Interpretamos que los pliegues E-O se formaron durante el cabalgamiento de las unidades y los NNE-SSO cuando comenzó la traslación de la Zona Interna hacia el O.

Palabras clave: superposición de pliegues; mantos; Alpujárride; Zona Interna Bética; España

Recibido: 5 de agosto de 2013 / Aceptado: 13 de diciembre de 2013 / Publicado: 24 de junio de 2014

Citation / Cómo citar este artículo: C. Sanz de Galdeano, A. Carlos López Garrido (2014). Structure of the Sierra de Lujar (Alpujarride Complex, Betic Cordillera). Estudios Geologicos, 70(1): e005. http://dx.doi.org/10.3989/egeol.41491.290.

Copyright: () 2014 CSIC. This is an open-access article distributed under the terms of the Creative Commons Attribution-Non Commercial (by-nc) Spain 3.0 License. 


\section{Introduction}

Sierra de Lujar is an area of interest because of the great development of its folds, fold superposition, and vergence changes. In this sense, it is one of the most spectacular zones of the Betic Cordillera. To explain the structure and geologic evolution of this sierra, many hypotheses have been proposed, but to date none has been supported by a map differentiating the various members of the Triassic carbonate series.

This sierra (Figs. 1 and 2) is located in the Betic Cordillera, which is formed by two main domains, the Internal and External zones. This cordillera also includes the Flysch Units, particularly well represented in the area of the Campo de Gibraltar, and Neogene basins formed over the two aforementioned domains.

The External Zone formed the sedimentary cover of the S and SE edges of the Iberian Massif and it is composed of Mesozoic to Tertiary sediments (it is beyond the scope of the present study).

Originally, the former sedimentary basin that later corresponded to the Internal Zone was situated to the E, in the western Mediterranean (Durand-Delga, 1980; Durand-Delga \& Fontboté, 1980; Wildi, 1983, Sanz de Galdeano, 1990), and towards the end of the Oligocene began to drift westwards. This Internal Zone is formed by four tectonically superimposed complexes which from bottom to top are the Nevado-Filabride, Alpujarride, Malaguide, and Dorsal. All these complexes were affected by Alpine orogeny, but only the first two underwent significant metamorphism in this epoch.

The present paper studies the Sierra de Lujar, belonging to the Alpujarride Complex. We present for the first time a map separating the different members of the Triassic stratigraphic series, enabling us to establish its complex structure, particularly in reference to the superposition of folds. Also its geologic evolution within the Betic Internal Zone is discussed.

\section{Background}

Many previous articles dealing with the structure of Sierra de Lujar discuss the autochthony or allochthony of the unit of Lujar. There is also a scientific controversy concerning whether the major folds exist, whether they are in normal or reverse position, and whether the structure was formed under compression or extension. Also its tectonic position within the Alpujarride units has

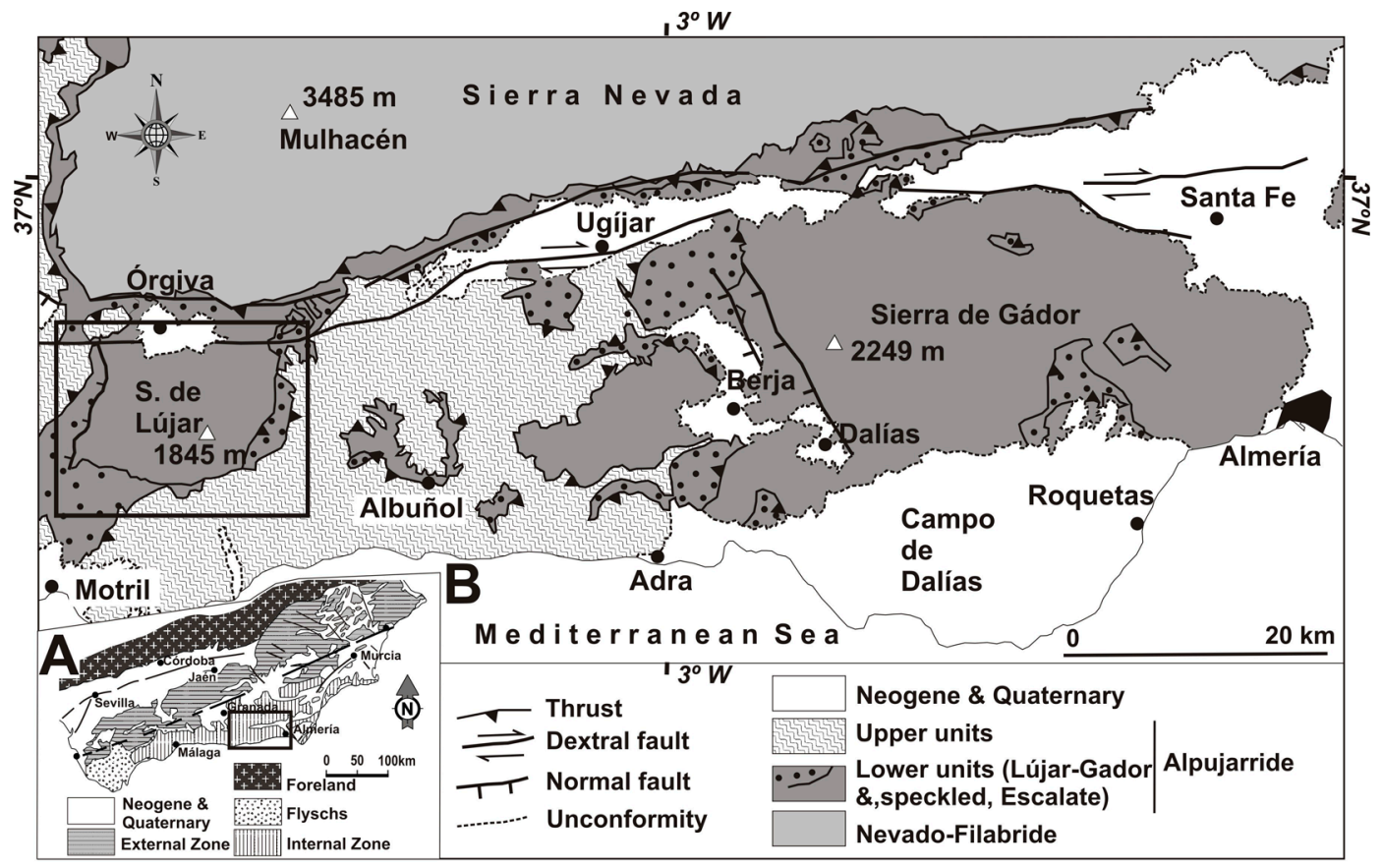

Fig. 1.-Geological sketch of the region where Sierra de Lujar is located. 


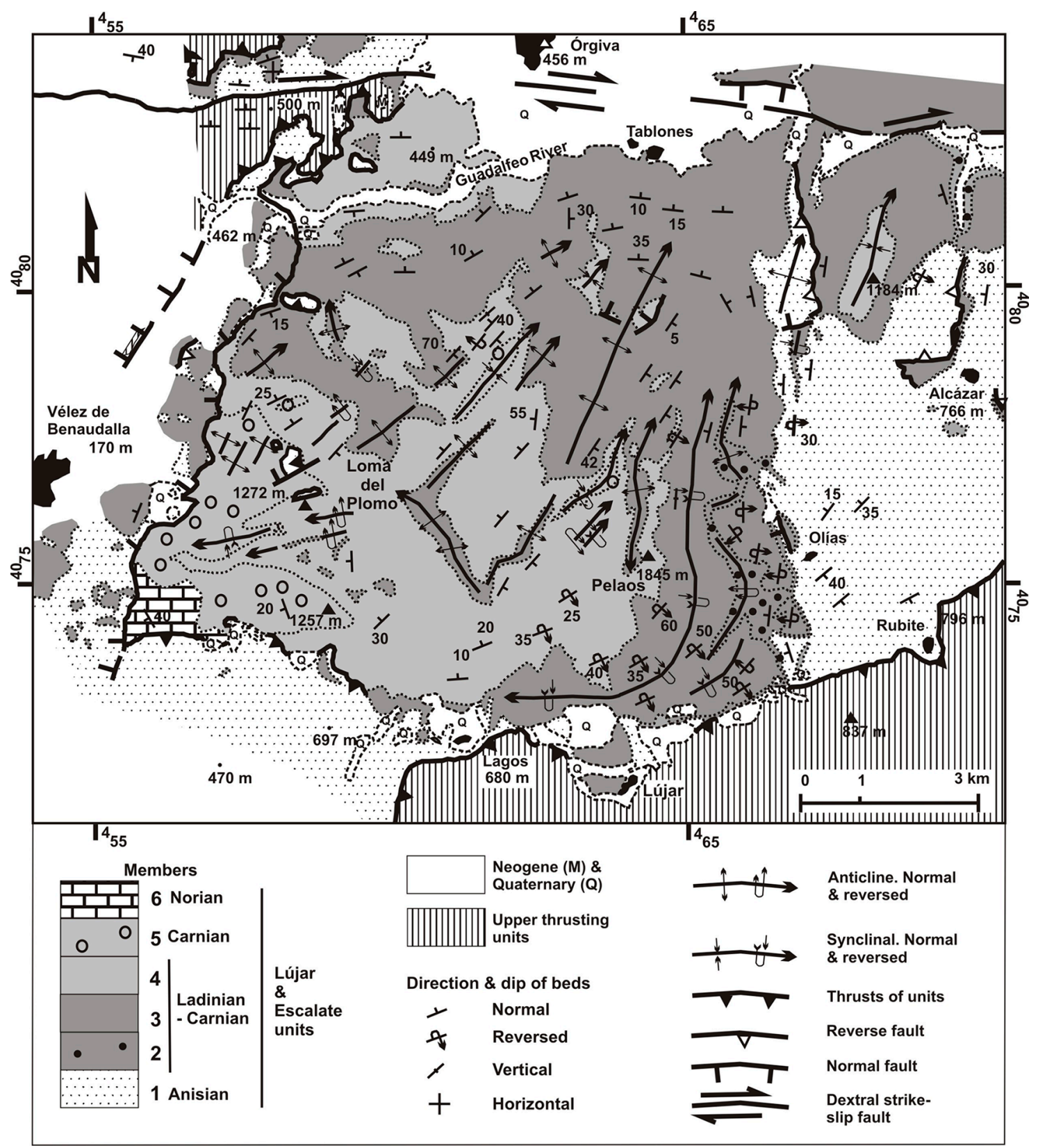

Fig. 2.-Main geological features of Sierra de Lujar.

been discussed, as well as other aspects concerning its mineralogy and hydrology.

Bemmelen (1927) described the allochthony of the Lujar unit and included it in the Alpujar ride (Alpujarriden), then defined as a complex. Westerwerd (1929) \& Staub (1934) also recognized the existence of nappes in this region. Banting (1933) advanced the hypothesis that Sierra de Lujar constituted a major reverse limb of a great fold "pli-nappe de Lujar-Gádor". In these years, the attribution of these materials to the Triassic was generally accepted.

Copponex (1957 and 1959) interpreted the folds of this sierra as being in a normal position, i.e. not reversed, whereas Boulin et al. (1966) and Boulin (1970) held that this sierra forms a great reverse fold. Aldaya (1968, 1969a \& b, 1970a \& c, 1981), Aldaya \& García Dueñas (1976) and Aldaya et al. 
(1979a and b) differentiated the Alpujarride units, south of Sierra Nevada, from bottom to top, into: Lujar, Castaras, Alcazar, Murtas, and Adra. In general, the metamorphic degree of these units progressively increases from the lower to the upper units. These authors did not present a real map of Sierra de Lujar as they did not differentiate the members of the Triassic carbonate succession of the Lujar unit. They contended that no reverse folds existed in the $\mathrm{S}$ and $\mathrm{E}$ of this sierra, and they interpreted the overturned contact between the carbonates and the phyllites as a nappe contact. Consequently, Aldaya and Aldaya et al. (ops. cit.) assigned the aforementioned phyllites to a different unit, the Alcazar unit. This is the crucial point to differentiate the Alcazar (and also the Castaras unit) from that of Lujar unit (or Lujar-Gador as was known, see Fallot, 1948).

Tectonic instabilities during the deposit of the Triassic carbonates, with breccias and intraformational folds, were cited in Lujar by Aldaya $(1970 \mathrm{~b})$ and at other points. These instabilities were also mentioned by Ovejero et al. (1982). The mineralizations of the Sierra de Lujar were studied by Tona (1973) and later by Ovejero et al. (op. cit.). This paper is a key work not only for the study of the fluorite and galena mineralizations, but particularly for presenting a map of facies covering the mineralized area. From this map the structure cannot be deduced clearly, but it was the only real cartography previously existing up to that time. Moreover, the description of the lithologic series and several geological cross-sections are also valid. Ewert (1976) contributed to the knowledge of these mineralizations and the lithologic sequences. Delgado et al. (1981) described the stratigraphic series of many Alpujarride units, including the Lujar unit.

Meanwhile, revising the structure of the Alpujarride Complex south of Sierra Nevada, Estévez et al. (1985) rejected the independence of the Castaras unit from the Lujar-Gador unit and gave the name of Escalate to the Alcazar unit because in the locality of Alcazar the differentiation of this unit from that of the Lujar-Gador is difficult, while in the area of Escalate (the gorge of the Guadalfeo river, before its flow into the sea) the unit of Alcazar, now Escalate, is the only one represented there. However, their study includes no map of the Sierra de Lujar and shows only two cross-sections. One presents the continuity of the structures between the area of the Sierra de Lujar and the Sierra de La Joya (to the NE of the first). The second cross-section goes from the SE to the NW of the Sierra de Lujar, and shows a major $\mathrm{N}$-verging reverse fold with two internal detachments.

Nevertheless, Cuevas et al. (1986 and 1990) and Cuevas (1988, 1989a, b and c) accepted the individuality of the Castaras and Lujar units as well as the tectonic separation between the sierras of La Joya and Lujar, based on a belt of mylonitic foliation. These authors indicate that, in the central area of the Alpujarride nappes, two main stages of thrusting occurred, to the NE and later to the NNW.

Simancas \& Campos (1988 and 1993) and Campos \& Simancas (1989) recognized north vergent overturned folds in Sierra de Lujar and the presence of internal detachments. Moreover, they point out the curved axis of the reverse syncline of the $\mathrm{S}$ of this sierra.

According to the interpretation of Orozco et al. (2004) and Orozco (2006), Sierra de Lujar (and other more eastern sectors as the tectonic window of Albuñol or Sierra de Gador) form part of a great reverse syncline (Fig. 1). These authors indicated that, in the northern part of the Sierra de Lujar, there are several low-angle normal faults, belonging to the "normal faults of the Contraviesa" (this name corresponding to the area situated eastern of Sierra de Lujar). In these papers, they argue the coexistence of compressive and extensional stages of deformation.

Several authors (Balanyá \& García-Dueñas, 1986; Azañón et al., 1993 and 1994; García-Dueñas et al., 1992; Crespo Blanc et al., 1993 a and b; Crespo Blanc, 1995, among many others) placed great importance on an extensional process starting from the end of the early Miocene (or somewhat late) and affecting the Betic-Rif Internal Zone and the Alboran Sea. According to this interpretation, most of the present contacts of the units have an extensional character.

Finally, there is a long system of dextral faults (Sanz de Galdeano et al., 1985; Martínez Martínez et al., 2006) (Fig. 1) and one of its faults forms the northern limit of the Lujar unit. 


\section{Geological setting and morphology of the Sierra de Lujar}

The units distinguished in the present study are, from bottom to top, Lujar, Escalate, Murtas and Adra, these two latter ones not being differentiated (Figs. 1 and 2). The Lujar (or Lujar-Gador) unit occupies the lower position in the Alpujarride tectonic pile and overlies the Nevado-Filabride Complex (details of this superposition and later movements of strike-slip and extension are beyond the scope of this paper). The Lujar-Gador unit does not outcrop westwards of the Sierra de Lujar, cover by the upper units.

Morphologically, Sierra de Lujar forms very high relief compared with the surrounding areas, reaching $1845 \mathrm{~m}$ a.s.1. in the highest peak, called Los Pelaos, in the SE part of the sierra (Fig. 2), falling sharply southwards (the locality of Lujar is only $500 \mathrm{~m}$ a.s.1.) and eastwards. The fall to the $\mathrm{W}$ and $\mathrm{N}$ is less sharp although it is abrupt and, to the N, the Guadalfeo River is at less than $200 \mathrm{~m}$ a.s.1.. In general, this sierra forms a kind of elevated dome.

\section{Stratigraphy of the Lujar unit and main features of the other units}

As indicated above, Sierra de Lujar belongs to the Lujar-Gador unit (Fig. 1) and shares the general stratigraphic features with those observed in other places where this unit outcrops. This unit presents a low degree of metamorphism, favouring the conservation of the sedimentary structures and fossils. For this reason, we here generally use the terms "dolomite" and "limestone" instead of "dolomitic" and "limestone" marble.

The Escalate unit is a tectonic duplication of the Lujar unit and consequently has the same stratigraphic sequence. The upper units are formed, in the study sector, only by schists and quartzites.

\section{Stratigraphic series of the Lujar unit}

\section{Member 1}

This member, situated at the bottom of the sequence, is made up of grey-blue phyllites. In its lowest outcrops, in the SW of Sierra de Lujar, the colour is slightly darker and can be considered thingrain schists, as indicated by Cuevas et al. (1990).

There are abundant levels of quartzites, particularly towards the top, and locally may be thicker than $20 \mathrm{~m}$, sometimes with light colours. These levels can even be cartographically distinguished from the phyllites (not in Fig. 2, in order simplify the map). Also, there are irregularly interbedded yellow calcschists, which become more abundant to the top.

This member is several hundred metres thick (the bottom is not visible) and its age is generally attributed to the Anisian (Delgado et al., 1981).

\section{Member 2}

At the top of the phyllites and quartzites, there is a progressive transition to levels of yellow calc-schist that finally become predominant, forming member 2. The thickness of these calc-schists varies, oscillating from about $1 \mathrm{~m}$ to 30 or $40 \mathrm{~m}$, as in the NE of Sierra de La Joya. Intercalated among the calcschists, appear levels of limestone, which in turn progressively gain predominance towards the top while the calc-schists become sporadic.

The thickness of this member varies greatly. In the $\mathrm{SE}$ of the Sierra de Lujar it is approximately $75 \mathrm{~m}$, while in other places it measures only several metres. This variability is owed to the constant changes in facies and also to dolomitization processes in many places.

This member shows signs of synsedimentary instability (Ovejero et al., 1982) with intraformational breccias and some slumps.

\section{Member 3}

This member is made up of dark-coloured dolomites, massive at many points and arrayed in thin laminae at other points. Locally, there are intercalations of dark marls, yellow at other sectors. Locally, "franciscana" facies (zebra dolomites) occur in this member.

This member is $350-450 \mathrm{~m}$ thick, but it should be considered that in many places this thickness includes member 2 , because locally the two members cannot be clearly distinguished. The age attributed by Delgado et al. (1981) to members 2 and 3 is Anisian-Ladinian. 


\section{Member 4}

It is formed by grey limestones arrayed in beds of $10-30 \mathrm{~cm}$, but locally the thickness is highly variable. At the bottom, levels of calc-schists separate the previous dolomitic member. Calc-schists are also intercalated along the member, particularly towards the top.

The contact between members 3 and 4 is easily distinguishable in many places, but not in others, where two features concur: a) dolomites of member 3 include more laminated beds, in many cases with marly character; and b) irregular dolomitization occurs in many places in such a way that, at a same level, the lithology changes from dolomite to limestone and vice versa. This distinction is more difficult in the NW area of Sierra de Lujar, a shady area with thick undergrowth that covers and obscures the contacts.

At many points of this member, intraformational breccias and slumps are abundant, as indicated by Aldaya (1970b) and Ovejero et al. (1982). Fossils are well preserved, as are the fucoid marks. In some places situated near the bottom, zebra dolomites also appear. Locally there are abundant nodules of white, grey, and black silex.

Basic interstratified volcanic rocks in the Sierra de Lujar, first indicated by Dimpault et al. (1968), are more abundant in this member.

The approximate thickness of this member is about $200 \mathrm{~m}$ and the attributed age is Carnian, possibly Ladinian towards the bottom (Delgado et al., 1981).

\section{Member 5}

The limit between members 4 and 5 is locally marked by levels of calc-schists which at some points measure more than $10 \mathrm{~m}$ thick. However, these are not always present along the contact or at least cannot be recognized for different reasons, such as the existence of soils. On the whole, member 5 is similar to the member 4 , and levels of dark dolomite, and intraformational breccias and slumps are much more abundant.

In the SW of Sierra de Lujar, the slump axes have a nearly N-S strike and verge to the W. The upper part of some of these folds are eroded and occupied by breccias.
Members 5 and 4 bear the greatest numbers of galena and fluorite mines of this sierra. There is also a huge number of trial excavations, some more than $100 \mathrm{~m}$ deep, made even without signs of mineralization.

Owing to the difficulty of differentiating members 4 and 5, the thickness measurements do not offer good reliability. In fact, the map of Fig. 2 includes both members at many places. The same applies to the cross-sections of Figs. 3 and 4, and therefore they present apparent distortions in the thickness. Where this member has been reliably differentiated, its thickness is about $150 \mathrm{~m}$, and its age is attributed to the Carnian (Delgado et al., 1981).

\section{Member 6}

It corresponds to dolomites arrayed in banks, with laminations and algal structures in the interior. The colour of the rock is grey to dark grey, but on the surface the dominant colour is lighter. This member is homogeneous and easily distinguishable from the lower member. It outcrops only in the SW of Sierra de Lujar.

The observable thickness is on the order of 200 $\mathrm{m}$, but its original value is not known in Sierra de Lujar because the possible upper members are not conserved. The attributed age (Delgado et al., 1981), here and in many other units, is Norian.

\section{Structure of Sierra de Lujar}

The most outstanding structural feature is the abundance and importance of folds (Figs. 2, 3 and 4) and their different orientations and even vergence (in the description of the folds, we cite only the larger ones, because smaller ones are abundant). We also describe the features of the main thrust referred to the Escalate and upper units.

\section{The folds of Sierra de Lujar}

The most important fold of Sierra de Lujar is the huge reverse syncline, previously cited in the references (Fig. 2; Fig. 4, IV; Fig. 5, A). This fold has a curved axis, E-W in the southern sector changing to $\mathrm{NNE}$ in the eastern sector; consequently the vergence changes (northward and westward, respectively). 

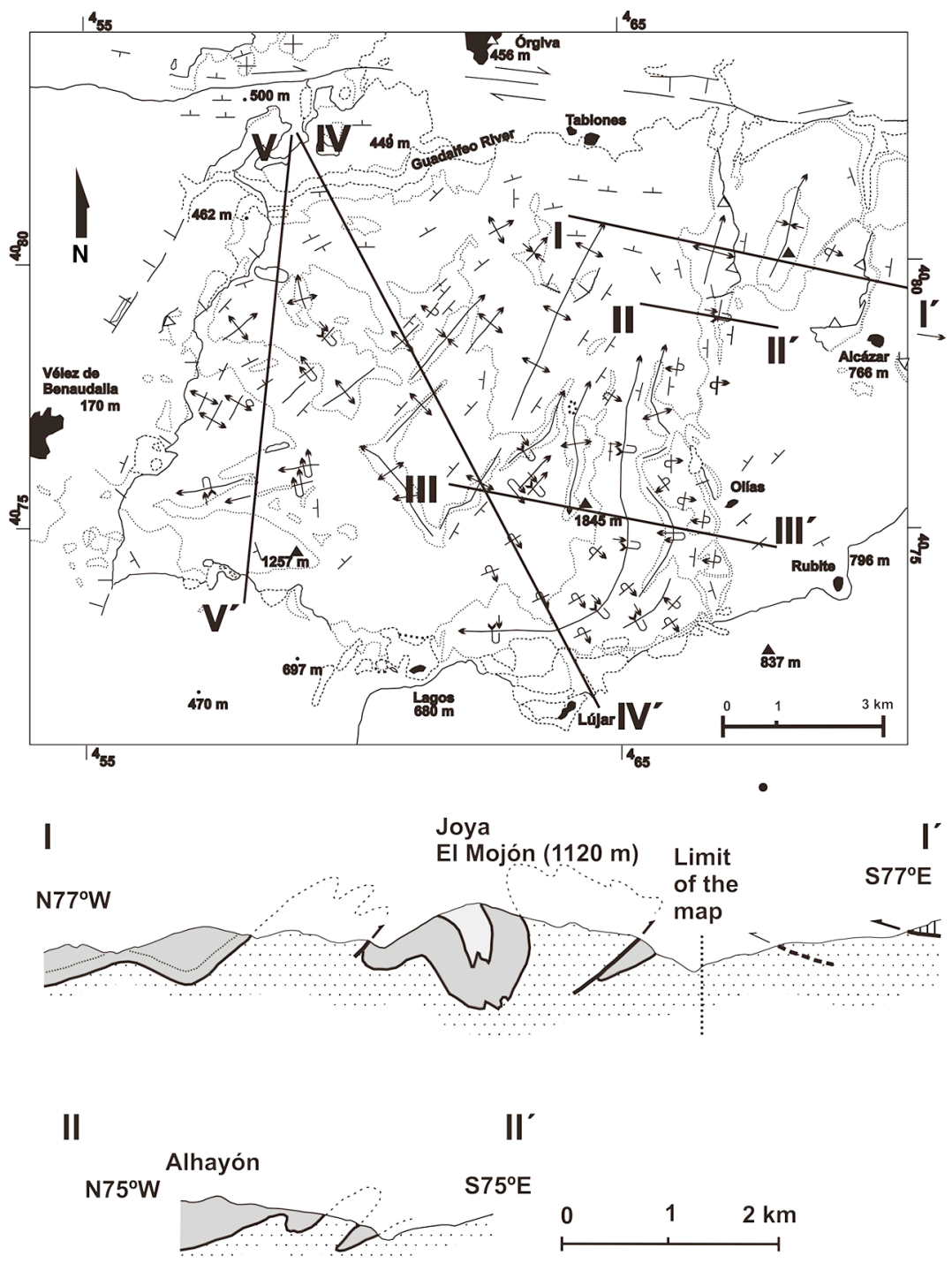

II"
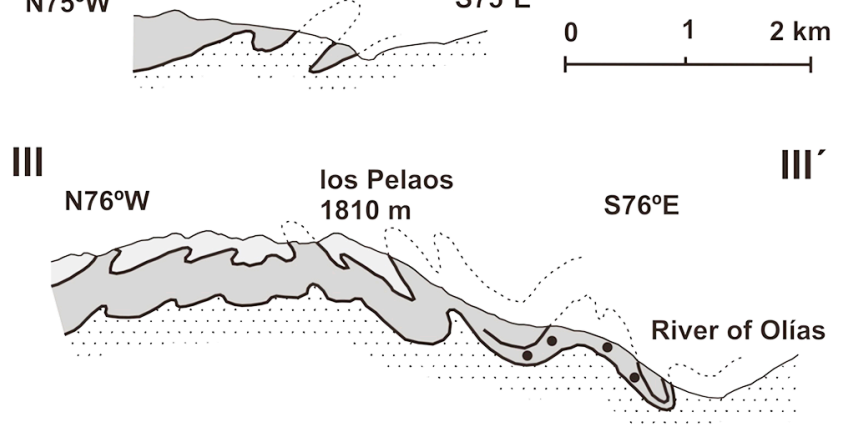

Fig. 3.-Geological cross-sections of the eastern part of Sierra de Lujar. The symbols are similar to those of Fig. 2. The geological sketch indicates the position of the cross-sections of this figure and those of Fig. 4.

In the eastern limb, phyllites and quartzites (top of member 1) change to calc-schist and limestones (bottom of member 2). Although generally reversed with a variable dip, $30-40^{\circ}$ to the vertical - this is a normal stratigraphic contact. This inversion continues at higher levels.

West, towards the locality of Lagos, the abovedescribed contact is no longer stratigraphic, but 

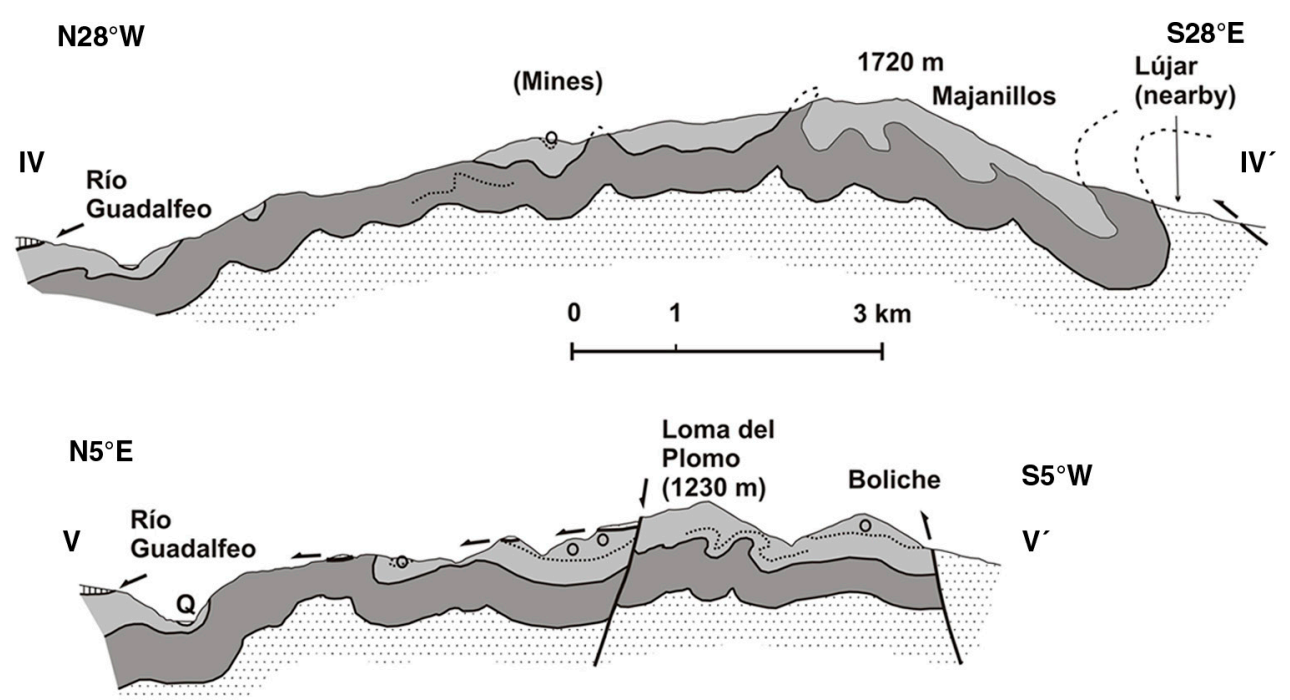

Fig. 4.-Geological cross-sections of the Sierra de Lujar. The symbols are similar to those of Fig. 2. Their position is marked in Fig. 3.

rather becomes a thrust. As a result, the phyllites cut through higher member of the series, and even those of the Norian (member 6). Moreover, there the phyllites are fine-grain schists, indicating also that the contact is tectonic.

From Lagos to the NE, the reverse limb, particularly the limestones of the member 4 , are greatly stretched and thinned. In some places the hinge of the fold is visible (Fig. 2; Fig. 3, III; and Fig. 5, B).

On the SE and E edge of Sierra de Lujar, a major E verging anticline divides the great syncline. The axes of both structures are parallel.

More to the NE, in the Sierra de La Joya, (crosssection I, Fig. 3) there is a syncline verging to the $\mathrm{E}$ and the same vergence has a thrust affecting it. The prolongation to the $\mathrm{S}$ of this structure of La Joya can be seen in cross-section II (Fig. 3). This structure, although with opposite vergences, represents the continuity from Sierra de Lujar to La Joya.

Inside Sierra de Lujar, to the N and W of the great syncline, there are many small and tightened reverse folds, anticlines, and synclines, particularly visible in the sector of Los Pelaos. Many of these folds have the same vergence as the great syncline, but others present opposite vergence (Fig. 6, A and B). More to the $\mathrm{N}$ and NW a great anticline appears (which in the Fig. 2 can be seen south of Tablones), the axis direction of which is NNE-SSW with normal limbs, not reversed. The existence of a large, deep valley along the axis of this anticline permits a good view of it.
Westwards, there are several NE-SW anticlines and synclines, some with reverse limbs and different vergences. Particularly, an anticline with NW vergence in the SW part and SE vergence in the NE part can be discerned. Some of these folds have knee hinges - that is, one of their limbs is practically vertical while the other has a minor dip (Fig. 5, C).

The structure of the northern border of Sierra de Lujar, coinciding with the valley of the Guadalfeo River, dips on the whole to the N, but there are several folds, some verging to the SE (not marked in Fig. 2).

East of Velez de Benaudalla, SW of Sierra de Lujar, there are some E-W reverse folds verging to the S (Fig. 6, C). These can be followed for several $\mathrm{km}$ to the S and SW of the locality of Fuente del Plomo.

Finally, an anticline with NNW-SSW direction is located approximately $3 \mathrm{~km}$ west of Los Pelaos. This runs transversal to all of the above-cited folds.

\section{The thrustings over the Lujar unit and other faults}

South of Sierra de Lujar near the localities of Rubite, Lujar, and Lagos appears a major thrust formed by schists and quatzites belonging to the Murtas-Adra units. The contact is clearly visible owing to the great lithologic contrast with the phyllites of the Lujar unit. To the E, beyond the limits of Fig. 2, this thrust is also visible and cuts through the materials of the Escalate 

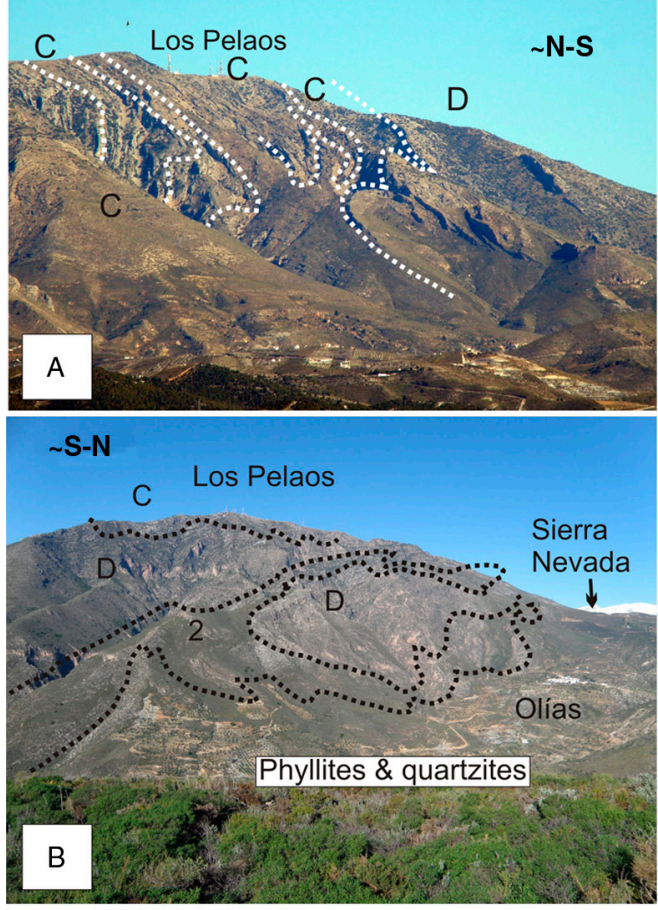

SE-NW

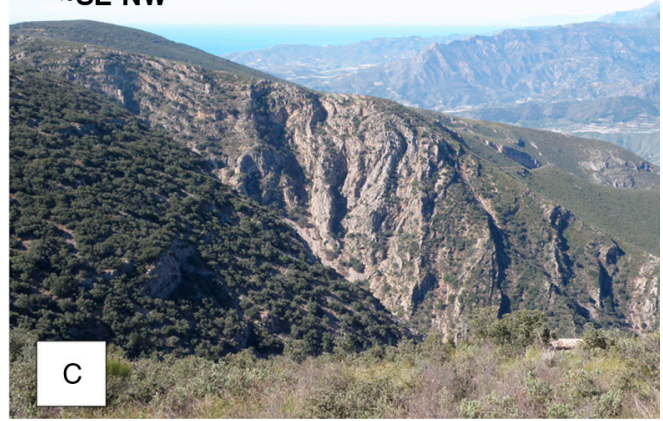

Fig. 5.-A) Part of the hinge of the great $\mathrm{N}$-verging syncline. Note the thinning of the reverse flank ( $D$ : dolomites of member 3, C: limestones of member 4). The distance between Los Pelaos and the lower parts of the dolomites is approximately 3 $\mathrm{km}$. B) Structure of the eastern border of Sierra de Lujar. An E vergent anticline affecting the great syncline is observed. The dashed lines correspond to contacts (meaning of the letters and number: 2: calc-schists and limestones of member 2, $D$ : dolomites of member 3, C: limestones of member 4). The general reverse position of this limb can be also seen as the phyllites and quartzites of member 1 overlie the carbonate succession. The N-S distance in this photo is about $6 \mathrm{~km}$. C) Knee hinge in a NW-SE anticline located in Fig. 2 is situated to the $\mathrm{N}$ of Loma del Plomo. The width of photo is $300 \mathrm{~m}$.

unit, totally or partially bevelling the carbonates situated above the phyllites (Fig. 3, I and Fig. 6, D). Northwards the same thrusting unit can be seen.

The Escalate unit can be easily differentiated from the Lujar unit to the S and W of Sierra de Lujar.
Nevertheless, to the E the distinction is not so easy. The limits between the two units can be distinguished only with a detailed map, separating the phyllites. As expressed above, the Escalate unit is actually a duplication of that of Lujar.

There are 3 or 4 klippes (one of them may correspond to sliding phyllites) of the Escalate unit above that of the Lujar (Fig. 2 and Fig. 4, V) near the Fuente del Plomo area. There, the thrusting surface is horizontal or slightly dipping to the $\mathrm{N}$, and striae at two points indicate a displacement of the top to the NNW and the NNE. The altitude of these klippes become progressively lower to the $\mathrm{N}$.

To the SW of the Sierra de Lujar, the contact between the two units is sharply inclined because it is affected by a later fault showing dextral components of movement.

On the western border of Sierra de Lujar, the contact with the Escalate unit is affected by a major normal fault, sinking the Escalate unit. It forms part of the system of faults that from the NE of Granada uplift Sierra Nevada and other sectors situated to the E, compared with those to the W, i.e. in the Granada Basin. This fault system reaches the sea (Sanz de Galdeano \& López Garrido, 2000).

Within the Sierra the Lujar, there are a number of small normal faults, some indicated in Fig. 2.

Finally, all these units are cut to the $\mathrm{N}$ (north of the Guadalfeo River) by a major dextral E-W fault forming part of the set of faults of the Alpujarran Corridor (Sanz de Galdeano et al., 1985; Martínez Díaz, 1998; Martínez Martínez et al., 2006).

\section{Discussion}

The Sierra the Lujar is one of the best examples of fold superposition in the Alpujarride Complex. Generally, in this complex, there is a superposition of NNE-SSW to N-S folds over approximately E-W folds (Sanz de Galdeano \& Andreo, 1995; Sanz de Galdeano, 1989 and 2009). The same can be deduced in the Sierra de Lujar.

A sequence in the formation process of the structures in the Sierra de Lujar is:

In an initial stage the E-W folds formed (in this case with SW vergence). The southern part of the great syncline also formed (verging to the $\mathrm{N}$ ), the reverse limb of which underwent major thinning. 

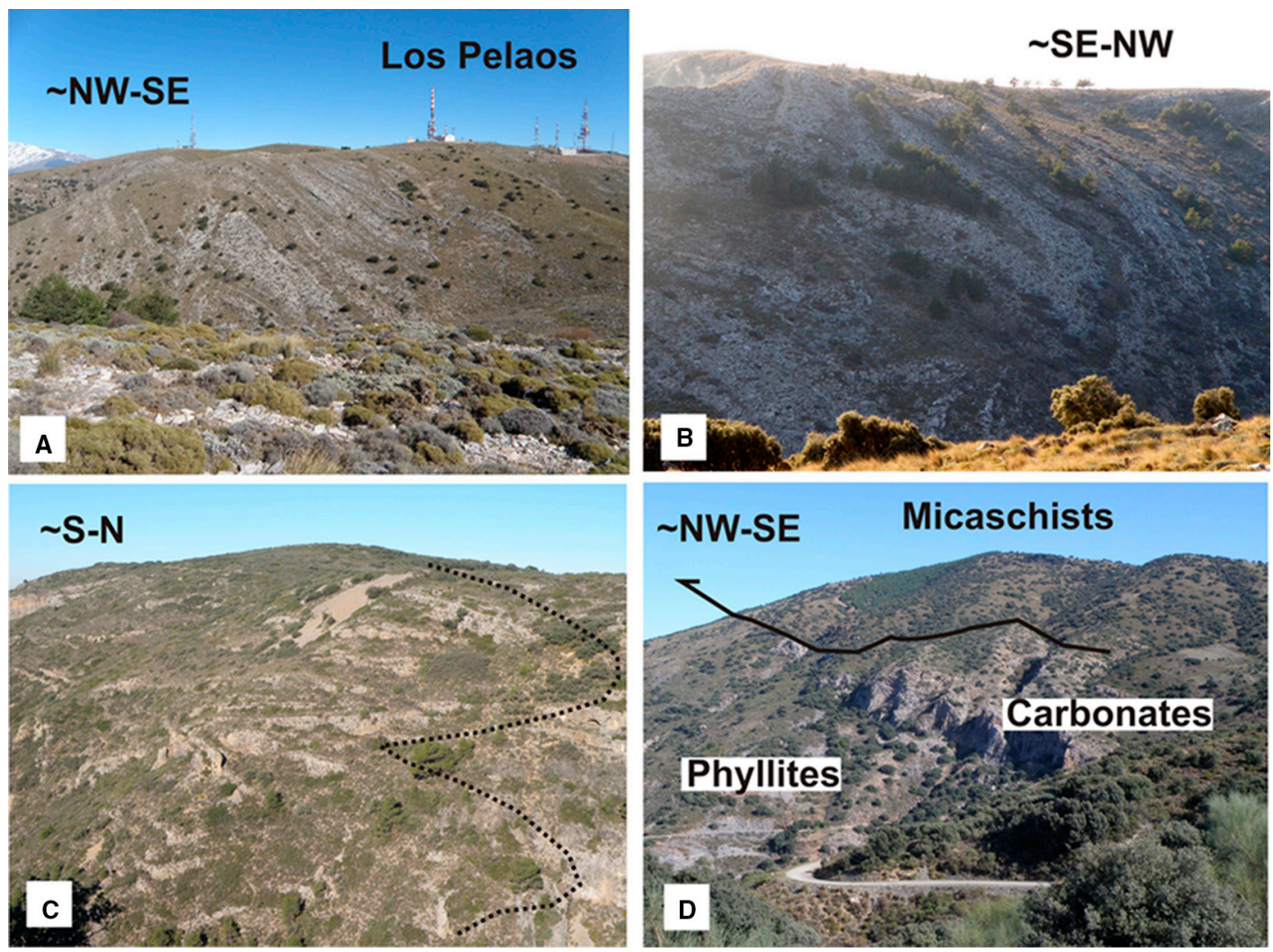

Fig. 6.-A) W verging tight folds in limestones of member 4 and dolomites of member 3 (to the right). The distance between the edges of this photo is about $250 \mathrm{~m}$. B) Photo of the opposite slope of A. Here the vergence is to the SE. The distance between the edges of this photo is about $100 \mathrm{~m}$. C) Several E-W folds situated near the Fuente del Plomo. From right to left and from the bottom to top, a syncline and an anticline can be seen, both overturned and verging to the $\mathrm{S}$. The distance between the hinges is about 70 m. D) Thrust of one of the upper units (here represented by schists) over the Escalate unit. The carbonates of Escalate Unit are cut through, even disappearing at several points. This sector is situated near the locality of Bargis, out of the map of the Fig. 2, E of that of Alcazar.

This stage was accompanied or immediately followed by the thrusting and duplication of the Escalate unit and the other upper units. During the process of the northward advance of the thrusting units, part of the upper members of the Lujar stratigraphic series was cut through.

In a second stage the NNE-SSW folds developed. The great syncline extended northwards on the $\mathrm{E}$ border of Sierra de Lujar, then forming a curved axis. Because of the lack of space an anticline verging in a opposite direction was formed in its interior during the syncline propagation, facilitating the displacement of the materials towards points of lesser resistance. For the same reason, the Sierra de La Joya also has an eastward vergence (Fig. 3, I).

The different vergences probably depend on the position in which the folds were formed, in such a way that the vergence can change even within a single fold, as occurs to the $\mathrm{W}$ of Los Pelaos. This is associated with different resistance in the horizontal as well as in the vertical within the unit during the formation of the structures.

We interpret the transversal NNW-SSE trending fold located $3 \mathrm{~km}$ west of Los Pelaos as a flexure marking the limit where the E-W folds are conserved from the rest of the unit, where the NNE-SSW folds predominate. It corresponds to the interference of both systems of folds and consequently was formed during the second stage.

This second stage, according to the present orientation of folds, implies a WNW-ESE compression. This agrees with the tectonic transport to the $\mathrm{W}$ undergone by the Internal Zone from the end of the Oligocene, i.e. early, and even middle, Miocene 
(Durand-Delga \& Fontboté, 1980, Wildi, 1983, Sanz de Galdeano, 1990, among others). It was possibly at the beginning of this tectonic transport when the second stage occurred, simultaneously forming the E-W dextral faults, one of which is situated on the northern edge of the Lujar unit.

The time for the extensional stage indicated by Balanyá \& García-Dueñas (1986), Azañón et al. (1993 and 1994), García-Dueñas et al. (1992), Crespo Blanc et al. (1993 a and b), and Crespo Blanc (1995), among others, seems too short and may need to be partially reinterpreted. In fact, during the progressive uplift of the Sierra Nevada and other sectors of the Betic Cordillera, previous tectonic thrusts were readjusted and new structures even appeared, such as low-angle normal faults. High-angle normal faults also occurred, such as that of the western edge of Sierra de Lujar. All of these faults contributed to the extension. However, in the Sierra de Lujar area the specific features of extension cited by the above authors are not evident.

It could be interpreted that the northward displacements observed on the surface of the klippes of the Escalate unit are low-angle normal faults, but the most probable interpretation is that of the initial thrusting process. The slight northward dip of the surface of the thrust is probably related to a certain general folding of the area similar to that in Sierra Nevada from the late Miocene, adopting its general antiformal shape.

Finally, the tectonic instability during the Triassic in the Lujar-Gador unit is a well known feature (MartínRojas et al., 2012), probably related to the rifting period affecting the Tethys and the initial opening of the Atlantic. This process also facilitated the emplacement of the above-mentioned basic volcanism.

\section{Conclusions}

The Sierra de Lujar constitutes one of the best examples of fold superposition in the Internal Zone. The differentiation of the members of the stratigraphic succession provides knowledge, for the first time, of its complex structure. The main feature is the existence of two systems of folds, an older E-W trending and a younger NNE-SSW trending, the latter being much better represented.

The more important fold system involves a great reverse syncline, verging to the $\mathrm{N}$ and $\mathrm{W}$ (depending on the places), the axis of which is convex to the SE, forming part of the $\mathrm{S}$ and $\mathrm{E}$ edges of this sierra. We interpret this as a consequence of the superposition of the NNE-SSW folds over a previous E-W fold. The lack of space determined changes in the initial vergence, shifting to an eastward vergence in the eastern area, as in the Sierra de La Joya, where there are also two reverse faults with the same vergence.

In the interior of the Sierra de Lujar, there is a succession of NNE-SSW trending anticlines and synclines, some with overturned limbs. The vergences change even within a single fold.

To the SW of the sierra, the E-W folds are better preserved, in this case with $\mathrm{SW}$ vergence.

The Sierra de Lujar is thrusted by the Escalate unit (a duplication of the Lujar unit) and by two other units, formed in this area mainly by schists. Inside Sierra de Lujar several small klippes of the Escalate unit crop out.

We interpret the E-W folds as related to the thrusting of the units, whereas those of NNE-SSW direction formed in relation to the westward drift of the Internal Zone. This drifting was also responsible of the formation of the dextral strike-slip faults of the Alpujarran Corridor, one of which limits the northern edge of the Lujar unit.

The western border of Sierra de Lujar is affected by a major normal fault, where the Escalate unit sinks. This fault forms part of the set of faults going from the western edge of Sierra Nevada to the coast, cutting through the Internal Zone and sinking its western block.

\section{ACKNOWLEDGEMENTS}

This work was conducted thanks to the projects CGL201231872, P09-RNM-5388 and CGL2010-21048 and the groups of research RNM- 370 and RNM 376 of the Junta de Andalucía. The careful revision of Profs. Martínez Díaz and Martín-Rojas greatly improved the paper.

\section{References}

Aldaya, F. (1968). Sobre la posición tectónica de la Sierra de Lujar (Prov. de Granada). Acta Geológica Hispánica, 3: 87-92.

Aldaya, F. (1969a). Sobre el sentido de los corrimientos de los Mantos Alpujárrides al Sur de Sierra Nevada (Zona Bética, prov. de Granada). Boletín Geológico y Minero de España, 83: 212-217. 
Aldaya, F. (1969b). Los mantos alpujárrides al S de Sierra Nevada (Zona bética, prov. de Granada). Acta Geológica Hispánica, 5: 126-130.

Aldaya, F. (1970a). Sobre la geometría de las superficies de corrimiento de los mantos alpujárrides del $\mathrm{S}$ de Sierra Nevada (Zona Bética, prov. de Granada). Cuadernos de Geología de la Universidad de Granada, 1: 35-37.

Aldaya, F. (1970b). Pliegues triásicos en la Sierra de Lujar, zona Bética, provincia de Granada (Nota preliminar). Boletín Geológico y Minero de España, 81(6): 593-600.

Aldaya, F. (1970c). La sucesión de etapas tectónicas en el dominio alpujárride. Cuadernos de Geología de la Universidad de Granada, 1: 159-181.

Aldaya, F. (1981). Mapa Geológico de España 1:50.000, hoja 1056 (Albuñol), Memoria. Instituto Geológico y Minero de España. 39 pp.

Aldaya, F. \& García-Dueñas, V. (1976). Les nappes alpujarrides au Sud et au Sud-Ouest de la Sierra Nevada (Cordillères bétiques, Andalousie). Bulletin de la Société géologique de France, 18(3): 635-639.

Aldaya, F.; García-Dueñas, V. \& Navarro Vila, F. (1979a). Los Mantos Alpujárrides del tercio central de las Cordilleras Béticas. Ensayo de correlación tectónica de los Alpujárrides. Acta Geològica Hispànica. Homenatge a Lluis Solé i Sabarís, 14: 154-166.

Aldaya, F.; Martínez García, E.; Díaz de Federico, A.; Puga, E.; García-Dueñas, V. \& Navarro-Vila, F. (1979b). Mapa Geológico de España 1: 50.000, hoja 1042 (Lanjarón), Memoria. Instituto Geológico y Minero de España, 65 pp.

Azañón, J.M.; Crespo-Blanc, A.; García-Dueñas, V. \& Orozco, M. (1993). Middle Miocene extensional faulting events and Alpujarride units in the Central Betics. Geogaceta, 14: 119-122.

Azañón, J.M.; García-Dueñas, V.; Martínez Martínez, J.M. \& Crespo-Blanc, A. (1994). Alpujarride tectonic sheets in the central Betics and similar eastern allochthonous units (SE Spain). Comptes Rendus de l'Académie des Sciences. Paris, 318(2): 667-674.

Balanyá, J.C. \& García-Dueñas, V. (1986). Grandes fallas de contracción y de extensión implicadas en el contacto entre los dominios de Alborán y Sudibérico en el Arco de Gibraltar. Geogaceta, 1: 19-21.

Banting, A.H. (1933). Sur le pli-nappe de Lujar-Gádor (Cordillères Bétiques). Proc. Kon. neder. Ak. Wetensch. 36: 98-106.

Bemmelen, R.W. van. (1927). Bijdrage tot de Geologie der Betische Ketens in de province Granada. Tesis Univ. Delft, 176 pp.

Boulin, J. (1970). Les Zones Internes des Cordillères Bétiques de Málaga à Motril (Espagne méridionale). Annales Hébert et Haug, Laboratoire de Géologie Historique, Faculté des Sciences de l'Université de Paris, Paris, 237 pp.
Boulin, J.; Dimpault Darcy, P. \& Leroy, H. (1966). Observations géologiques en Sierra de Lujar (Cordillères Bétiques internes, Espagne). Bulletin de la Société géologique de France 8: 585-591.

Campos, J. \& Simancas, J.F. (1989). Los pliegues tumbados del Manto de Lujar y su modificación por el sistema de cabalgamientos frágiles (Complejo Alpujárride, Cordillera Bética). Geogaceta, 6: 50-53.

Copponex, J.P. (1957). Sobre un sistema de relevos de mantos en los Alpujárrides occidentales. Notas y Comunicaciones del Instituto Geológico y Minero de España, 47: 1-6.

Copponex, P. (1959). Observations géologiques sur les Alpujarrides occidentales (Cordillères Bétiques, Espagne). Boletín Geológico y Minero de España, 70: 79-208.

Crespo-Blanc, A. (1995). Interference pattern of Miocene extensional systems in the Alpujarride Complex $(\mathrm{N}$ of Sierra Nevada, Betic Cordillera). Journal of Structural Geology, 17(11): 1559-1569. http://dx.doi. org/10.1016/0191-8141(95)E0044-D.

Crespo-Blanc, A.; García-Dueñas. \& Orozco, M. (1993a). Systèmes en extension dans la Chaîne Bétique Centrale: que reste-t-il de la structure en nappes du complexe Alpujarride? Comptes Rendus de l'Académie des Sciences de Paris, 317(2): 971-977.

Crespo-Blanc, A.; Orozco, M. \& García-Dueñas, V. (1993b). Extension versus compresssion during the Miocene tectonic evolution of the Betic Chain. Late folding of normal fault systems. Tectonics, 13(1): 78-88. http://dx.doi.org/10.1029/93TC02231.

Cuevas, J. (1988). Microtectónica y metamorfismo de los mantos alpujárrides del tercio central de las Cordilleras Béticas (entre Motril y Adra). Tesis Doctoral. Universidad del País Vasco, 283 pp.

Cuevas, J. (1989a). Microtectónica y metamorfismo de los mantos alpujárrides del tercio central de las Cordilleras Béticas (entre Motril y Adra). Parte I: Litología y estructuras asociadas a D1, D2 y D3. Boletín Geológico y Minero de España, 100(4): 497-540.

Cuevas, J. (1989b). Microtectónica y metamorfismo de los mantos alpujárrides del tercio central de las Cordilleras Béticas (entre Motril y Adra). Parte II: Las zonas miloníticas. Boletín Geológico y Minero de España, 100(5): 719-766.

Cuevas, J. (1989c). Microtectónica y metamorfismo de los mantos alpujárrides del tercio central de las Cordilleras Béticas (entre Motril y Adra). Parte III: La estructura interna del Manto de Adra. Las traslaciones hacia el norte. Discusión y conclusiones. Boletín Geológico y Minero de España, 100(6): 935-970.

Cuevas, J.; Aldaya, F.; Navarro-Vila, F. \& Tubía, J.M. (1986). Caractérisation de deux étapes de charriage principales dans les nappes Alpujarrides centrales (Cordillères Bétiques, Espagne). Comptes Rendus de l'Académie des Sciences de Paris, 302(2): 1177-1180. 
Cuevas, J.; Aldaya, F.; Navarro-Vilá, F. \& Tubía, J.M. (1990). Structure of the Alpujarrides on the Southern and Eastern border of the Sierra de Lujar. Estudios Geológicos, 46: 209-216. http://dx.doi.org/10.3989/ egeol.90463-4452.

Delgado, F.; Estévez, A.; Martín, J.M. \& Martín Algarra, A. (1981). Observaciones sobre la estratigrafía de la formación carbonatada de los mantos alpujárrides (Cordilleras Béticas). Estudios Geológicos, 37 : 45-57.

Dimpault Darcy, P.; Juteau, Th. \& Leroy, H. (1968). Sur la présence de roches vertes interstratifiées dans la Sierra de Lujar (Cordillères Bétiques internes, Espagne). Étude pétrographique et chimique. Bulletin de la Société géologique de France, 10(1): 43-48.

Durand-Delga, M. (1980). La Méditerranée occidentale: étape de sa genèse et problèmes structuraux liés à celle-ci. Livre Jubilaire de la Société géologique de France, 1830-1980. Mémoire hors série, 10: 203-224.

Durand-Delga, M. \& Fontboté, J.M. (1980). Le cadre structural de la Méditerranée occidentale. 26 Congrès. Géol. Intern., Paris. Les Chaînes alpines issues de la Téthys. Mémoires de Bureau de Recherche Géologique et Minière, 115: 67-85.

Estévez, A.; Delgado, F.; Sanz de Galdeano, C. \& Martín Algarra, A. (1985). Los Alpujárrides al Sur de Sierra Nevada. Una revisión de su estructura. Mediterránea, 4: 5-32.

Ewert, K. (1976). Estratigrafía, litología y mineralizaciones del Manto de Lujar (Zona Bética). Stvdia Geologica, 11: 109-120.

Fallot, P. (1948). Les Cordillères Bétiques. Estudios Geológicos, 8: 83172.

García-Dueñas, V.; Balanyá, J.C. \& Martínez-Martínez, J.M. (1992). Miocene extensional detachments in the outcropping basement of the northern Alboran basin (Betics) and their implications. Geo-Marine Letters, 12(2/3): 88-95. http://dx.doi.org/10.1007/ BF02084917.

Martin-Rojas, I.; Somma, R.; Delgado, F.; Estévez, A.; Iannace, A. \& Zamparelli, V. (2012). The Triassic platform of the Gador-Turon unit (Alpujarride Complex, Betic Cordillera, S Spain): climate vs. tectonic factors in controlling platform architecture. Facies, 58(2): 297-323. http://dx.doi.org/10.1007/ s10347-011-0275-z.

Martínez Díaz, J.J. (1998). Neotectónica y Tectónica Activa del sector centro-occidental de la región de Murcia y sur de Almería. Tesis Doctoral. Universidad Complutense de Madrid, 466 pp.

Martínez-Martínez, J.M.; Booth-Rea, G.; Azañón, J.M. \& Torcal, F. (2006). Active transfer fault zone linking a segmented extensional system (Betics, southern Spain): Insight into heterogeneous extension driven by edge delamination. Tectonophysics, 422: 159-173. http://dx.doi.org/10.1016/j.tecto.2006.06.001.
Orozco, M. (2006). Las Alpujarras al S de Granada. Interpretaciones sobre su estructura e influencia de las mismas en las propuestas de evolución tectónica del extremo occidental del Cinturón Alpino Mediterráneo. Revista de la Sociedad Geológica de España, 19(1/2): 113-141.

Orozco, M.; Álvarez-Valero, A.M.; Alonso-Chaves, F. \& Platt, J.P. (2004). Internal structure of a collapsed terrain: The Lujar syncline and its significance for the fold- and sheet-structure of the Alborán Domain (Betic Cordilleras, Spain). Tectonophysics, 385: 85-104. http://dx.doi.org/10.1016/j.tecto.2004.04.025.

Ovejero, G.; Tona, F.; Marín, J.M.; Gutiérrez, A.; Jacquin, J.P.; Servajean, G. \& Zubiaur, J.F. (1982). Las mineralizaciones estratiformes $\mathrm{F} 2 \mathrm{Ca}-\mathrm{Pb}$ en las dolomías triásicas de Sierra de Lujar (Cordilleras Béticas, España). Boletín Geológico y Minero, 93(6): 15-35.

Sanz de Galdeano, C. (1989). Estructura de las Sierras Tejeda y de Cómpeta (Conjunto Alpujárride, Cordilleras Béticas). Revista de la Sociedad Geológica de España. Madrid, 2: 78-84.

Sanz de Galdeano, C. (1990). Geologic evolution of the Betic Cordilleras in the Western Mediterranean, Miocene to the present. Tectonophysics, 172: 107-119. http://dx.doi.org/10.1016/0040-1951(90) 90062-D.

Sanz de Galdeano, C. (2009). Estructura de los mármoles alpujárrides situados entre Calahonda y Castell de Ferro (Cordillera Bética, provincia de Granada). Estudios Geológicos, 65(2): 133-146. http://dx.doi. org/10.3989/egeol.39972.075.

Sanz de Galdeano, C. \& Andreo, B. (1995). Structure of Sierra Blanca (Alpujarride Complex, West of the Betic Cordillera). Estudios Geológicos, 51: 43-55. http://dx.doi.org/10.3989/egeol.95511-2282.

Sanz de Galdeano, C. \& López-Garrido, A.C. (2000). Las fallas tortonienses a cuaternarias entre Granada y la Costa: el límite occidental del Nevado-Filábride y de las unidades alpujárrides inferiores. Revista de la Sociedad Geológica de España, 13(3-4): 519-528.

Sanz de Galdeano, C.; Rodríguez Fernández, J. \& López Garrido, A.C. (1985). A strike-slip fault corridor within the Alpujarra Mountains (Betic Cordilleras, Spain). Geologische Rundschau, 74(3): 641-655. http://dx.doi.org/10.1007/BF01821218.

Simancas, J.F. \& Campos, J. (1988). La estructuración de componente Norte de los Mantos Alpujárrides en el sector central de la Cordillera Bética. II Congreso Geológico España. Sociedad Geológica de España, 27-33.

Simancas, J.F. \& Campos, J. (1993). Compresión NNWSSE tardi a postmetamórfica, y extensión subordinada, en el Complejo Alpujárride (Dominio de Alborán, Orógeno Bético. Revista de la Sociedad Geológica de España, 6(1,2): 23-35. 
Staub, R. (1934). Der Deckenbau Südspaniens in den Betischen Cordilleren. Vierteljahresschrift de Naturf. Gesellsch in Zürich, 79: 271-332.

Tona, F. (1973). Positions des horizons dolomitiques minéralisés en fluorine et galène au sein des sédimentes triassiques de la Sierra de Lujar (Grenade). Évolution et géochimique. Thèse 3ème cycle. Université de Paris VI, 166 pp.
Westerveld, J. (1929). De bouw der Alpujarras en het tektonische verband der oostelijke betische ketens. Thesis. Proesfschrift Delft, 120 pp.

Wildi, W. (1983). La chaîne tello-rifaine (Algérie, Maroc, Tunisie): structure, stratigraphie et évolution du Trias au Miocène. Revue de Géologie Dynamique et de Géographie Physique, 24(3): 201-297. 